\title{
PLACE AND ROLE OF PHYSICAL ACTIVITY IN THE LIVES OF THE ELDERLY AND DISABLED PEOPLE
}

\author{
Barbara Bergier
}

\author{
Pope John Paul II State School of Higher Education
}

Bergier B. (2014), Place and role of physical activity in the lives of the elderly and disabled people. Health Problems of Civilization 2 (8), p. $10-14$

Summary: The role of physical activity in the healthy lifestyle is a recurring element of surveys at every stage of the human life. The fact that people live longer indicates a necessity for studying the issue of physical activity of the elderly and disabled people. This review of researches reveals issues concerning physical activity of the elderly in Poland, and in other countries. Moreover, the study relates to the problem of physical activity among the elderly with disabilities. Researches show that this subject matter is present in the domestic studies relatively rarely. Results of surveys from other countries also concern issues of the elderly at around 80 years of age. The authors indicate the significant role of physical activity among the elderly, and the accompanying barriers.

Key words: physical activity, the elderly, disabled people

\section{Introduction}

The extension of human life in Poland and in other countries is connected to the issue of people's disability, which generates new social, and economic challenges. According to the research of Zatoński et al. (2011), the life expectancy of people born in Europe in 2002 will be the highest in case of men in Sweden - the age of 77.7, whereas the average life expectancy in Poland will be 70.3. The forecasted women's life is to be the highest in Spain - the age of 82.2, and in Italy - 83.1, whereas the average life expectancy for women in Poland is 78.8. It should be pointed out that the predicted life expectancy for Poles places us among the new European Union member states. For instance, in Latvia the men life expectancy reaches 64.7, and women in Romania - 74.7, whereas the lowest European rates are in Russia: the age of men - 58.9 and women - 71.9.

The world leaders of the issue of physical activity (Blair et al.) indicate its significant health-improving function of at every stage of human life.

The contemporary researchers (Bouchard et al. 2007) point out that the limiting of physical activity by the elderly causes among others: metabolic dysfunctions, decline of physical endurance, and increase in the number of cardiovascular diseases.

The latest studies of other countries provide results of researches concerning physical activity among the disabled elderly (Burns 2009, Freeman, Selmi 2010, Gray et al. 2012, Kerr et al. 2012, Sirkka et al. 2012). The current studies of physical activity among the disabled elderly in Poland are relatively rare.

The publishing of Osiński's book (2013) in our country is worth emphasizing, because it discusses the subject of physical activity among the elderly.

\section{Physical activity of adults in Poland}

The first studies of physical activity of adults in Poland on a large population were carried out by Drygas et al. (2005). They demonstrated that 37\% of women and $32 \%$ of men do not perform any exercises lasting min. 30 minutes daily in their free time. A percentage of people performing the given satisfactory amount of exercises during most weekdays is $38 \%$ of men and $34 \%$ of women. It should be noted that there are wide vari-

Adress for correspondence: Barbara Bergier, Pope John Paul II State School of Higher Education, Sidorska 95/97, Biała Podlaska e-mail: barbara.bergier@wp.pl, phone +48 (83) 3449902

Tables: 0, Figures: 0, References: 49, Full text PDF www.hpc.edu.pl Copyright (C) Pope John Paul II State School of Higher Education In Biała Podlaska, Sidorska 95/97, 21-500 Biała Podlaska Indexation: Index Copernicus, Polish Ministry of Science and Higher Education. This is an open-access article distributed under the terms of the Creative Commons Attribution Non-commercial License (http://creativecommons. org/licenses/by-nc/3.0), which permits use, distribution, and reproduction in any medium, provided the original work is properly cited, the use is non-commercial and is otherwise in compliance with the license. 
ations in separate Voivodeships of our country. Most people perform satisfactory physical activity in Lubelskie and Opolskie Voivodeships regarding both men, and women - respectively $51 \%$ and $47 \%$, and $50 \%$ and $46 \%$. The lowest percentage of performing recommended activity was observed among men in Podlaskie - 26\%, and Śląskie - 32\%, and among women in Pomorskie - 25\% and Śląskie - 25\%.

In the summary, the author (Drygas et al. 2005) points out that physical activity of the Polish society studied in 2000-2004 was higher than in the 90. of the previous century.

Unfortunately, physical activity becomes lower with age, especially after taking up a job. According to researches of the Polish Central Statistical Office (GUS), the number of people doing exercises systematically (minimum once a week) aged 20-24 makes circa 32\%, aged 45-49-13\%, and in the oldest groups considerably lower - aged 65-70 - 9\%, aged 75 and older - only 4\%. The surveys of the Polish Central Statistical Office (GUS) show that $14.2 \%$ of people did exercises once a week, $10.6 \%$ - twice, $6.2 \%$ - three times, $4.8 \%$ - four, or five times, and $5.7 \%$ - six or more times a week. It is worth noticing that the results are less favourable when compared to results from 2000 .

The first nationwide study in which the international standard questionnaire (IPAQ - short version) was used was presented by Piątkowska (2010). It enabled the comparative analysis of Poland and other countries. As a result of these surveys it was stated that physical activity of Poles and Europeans is at the similar level. However, Poles do not perform recreational activities, but compensate for it in another fields of general activity.

The current studies concerning physical activity of the elderly show many positive sides of the proper role of physical activity in their lives. The survey of physical activity of women aged 55-75 in Poland (Knapik et al. 2011) reveal the relationship between the level of physical activity and physical and mental health of women, and the decrease in physical activity and self-esteem over the age of 60 .

Surveys of Gabryelewicz and Mandecka (2013) point out that the regular physical activity of the elderly may contribute to the prevention of cognitive disorders and slow down the progress of Alzheimer. On the other hand, Bujanowska-Fedak et al. (2013) performed a complex geriatric evaluation of people over 60 in the Lower Silesia with reference to the effectiveness of walking, balance, and coordination. Good results were reported for walking -with worse results of women, and problems with coordination, balance and walking in the group of people aged 75 and more.

Surveys of Drobnik et al. (2010) show that performing physical activity in youth influences its maintaining at the following stages of live, as well as at the old age.

\section{Survey of physical activity of the elderly in other countries}

Surveys of foreign authors to a large extent concern physical activity of the oldest individuals. The American studies (Church et al. 2013) show that an active lifestyle influences positively the functioning of people aged between 70 and 89.

Results of survey of the same group of people (Chale-Rush et al. 2010) point out that factors such as gender, BMI, signs of depression, age, and amount of medicines should be taken into consideration in order to prevent disability.

Studies of Patel et al. (2006) in Italy of a group of people of average 75 years of age indicate that people who were more physically active in their middle age, were more mobile in the old age.

The survey of physical activity of disabled people in Poland is one of the most important scientific problems studied by the employees of the State Higher School in Biała Podlaska. The university realized two central projects of the State Fund of People with Disabilities.

As a result of the project "Social conditioning of the disabled people's participation in tourism and recreation in the Eastern Poland", many publications were published (Bergier J. et al. 2007, 2011, Bergier B. et al. 2007, 2010, 2013, Kubińska et al. 2013).

The second project "Determinants of professional activity of disabled people residing countryside" was co-financed by the State Fund for Rehabilitation of People with Disabilities (PFRON) resulted in the preparation of 4 volumes of monographs (Żbikowski et al. 2012).

The project of the Voivodeship Employment Office titled "Determinants of professional activity of disabled people residing countryside in the Lubelskie Voivodeship" was financed by the European Social Fund in terms of the Human Capital Operational Programme. Three studies were published (Bergier J., Tomczyszyn 2011, Bergier J. et al 2012, 2013).

One of the most difficult scientific problems, which is the evaluation and analysis of the physical ability of the elderly with disabilities, has gained the attention of researchers recently. 
Burns et al. (2009) indicated the numerous barriers appearing in the countryside with using recreational activities. Freeman and Selmi (2010), who carried out surveys in Canada and France, recommend increasing touristic opportunities for disabled people. Gray et al. (2012) created a review of infrastructure for physical activity and proposed facilities to be introduced. Sirkka et al. (2012), Kerr et al. (2012) also pointed out the necessity to introduce new technologies in the active rehabilitation and recreation of the elderly. Researches carried out recently on physical activity of the elderly with disabilities prove the social specificity of the problem.

\section{Conclusions}

The extension of human life brings new challenges to physical activity, which is extremely important factor in their lifestyle. It is worth noticing on the example of Poland that the predicted lifetime of people born at the beginning of this century will reach the age of 70 (Zatoński et al. 2011).

The first researches on physical activity in our country on a large population brought unfavourable results, worse for women than for men (Drygas et al. 2005). Even though authors pay attention to the fact that physical activity in 2000-2009 is higher than at the end of the previous century, they point out that most adult Poles do not fulfil requirements recommended by experts.

It is also emphasised that physical activity is decreasing along with taking up a job, and falls systematically, especially at the age of 65-74, and the most after 75 year of age (GUS 2009).

In order to trace changes in physical activity it is necessary to use the same, or similar evaluating tool.

Researches of Piątkowska (2010) with the use of the International Physical Activity Questionnaire (IPAQ) allowed for comparison with other countries, and showed that physical activity of Poles is similar to that of other Europeans. However, the Polish citizens are characterised with a lower recreational activity, at the expense of a bigger share of domestic activities. Surveys of physical activity of citizen of 6 European countries, including Poland (Drygas et al. 2001), indicated a very low recreational activity of Poles. This problem is reinforced by the biggest rates in the sedentary lifestyle for Poland.

Studies on physical activity of the elderly in Poland are relatively limited (Knapik et al. 2011, Gabrylewicz and Mondrecka, 2013; Bujanowska-Fedak et al. 2013; Drobnik et al. 2010) and relate mainly to people at the age of 60 . They indicate relationship between physical activity and a healthy lifestyle. They indicate a relation between the level of physical activity and a healthy lifestyle.

Research conducted by foreign authors concerning in a larger extent the oldest persons, that is at the age over 70 years old (Patel et. al. 2006, Chale-Rush 2010, Church et. al. 2013). Also this research indicates a beneficial impact of physical activity on the functioning of persons in the oldest age group.

Studies of physical activity of older people with the use of the same tool (IPAQ) in Poland are of contributory nature (Knapik et al. 2011, Biernat 2011, Pańczyk 2010), therefore, it is difficult to assess the physical condition of this age group of Poles. So far conducted studies on physical activity of older people have all shown a beneficial effect on the quality of life of older people (Osiński 2002, 2013, Borowiak, Kostka 2003, Nowak 2009, Kübler, Wójcik- Grzyb 2010, Rowiński, Dąbrowski 2011). It can therefore be assumed that the possible systematic physical activity of older people affects the improvement of their functional efficiency and eases the process of aging. Modern researchers (Bouchard et al. 2007) also show that the restriction of physical activity among the elderly causes, among others, deterioration in metabolic function, loss of function and increased occurrence of cardiovascular diseases.

Authors dealing with the physical activity of people with disabilities conduct new exploration research in terms of their participation in the tourism and recreational activity (Kubińska et al. 2011, Bergier B. et al. 2010, 2013). The results of these studies indicate that people with disabilities who have a lot of free time, were involved in tourist trips and physical activities to a small extent. Their main tourist trips concerned rehabilitation, bus trips and stays in the sanatorium. Among their modest physical activity they tend to prefer walking and gymnastics. As some of the obstacles of their participation in physical activities they indicate the high cost of fees related to such activities. You could say that the recommended physical activity for people with disabilities in Polish conditions is still very difficult to be implemented.

\section{References:}

1. Bergier B., Bergier J., Grudniewski T. (2007), Free time of the disabled from eastern provinces of Poland. Annales Universitatis Mariae Curie-Skłodowska. Sectio D. Medicina. Vol. 62, supl. 18, nr 1, s. 196-200

2. Bergier B., Bergier J., Kubińska Z. (2010), Environmental determinants of participation in tourism and recreation of people with varying degrees of disability. Journal of Toxicology and Environmental Health, Part A Vol. 73, iss. 17-18, s. 1134-1140 
3. Bergier B., Kubińska Z., Bergier J. (2013), Interests and needs for participation in tourism among disabled from eastern regions of Poland. Annals of Agricultural and Environmental Medicine, vol. 20, No. 4, s. 807-811

4. Bergier J., Dąbrowski D., Żbikowski J. (2011), Conditioning of participation of disabled males and females from eastern regions of Poland in tourism and recreation, Annals of Agricultural and Environmental Medicine, Vol. 18 (2), s. 350-354

5. Bergier J., Tomczyszyn D. (2011), Determinanty aktywności zawodowej osób niepełnosprawnych zamieszkałych na obszarach wiejskich $w$ województwie lubelskim: raport z badań. Koordynator projektu J. Bergier; koordynator merytoryczny D. Tomczyszyn. Państwowa Szkoła Wyższa Biała Podlaska.

6. Bergier J., Tomczyszyn D., Romanowicz W. (2012), Wykorzystanie czasu wolnego osób niepełnosprawnych z obszarów wiejskich województwa lubelskiego. Zamojskie Studia i Materiały. Seria Fizjoterapia, R. 14, z. 1, s. 147-156

7. Bergier J., Tomczyszyn D., Romanowicz W. (2013), Aktywizacja zawodowa kobiet niepełnosprawnych z obszarów wiejskich woj. lubelskiego: Niepełnosprawność i Rehabilitacja, R. 13, nr 2, s. 24-36

8. Bergier J., Żbikowski J., Stelmach M. (2007), Salubrious Values of Sport and Recreational Activities in the Option of Disable Inhabitants of Rural Areas of the Lublin Province. Polish Journal of Environmental Studies Vol.16, no. 5c, Part 2, s. 769-772

9. Biddle S. (1995), Exercise and psychosocial health. Res. Quart. Exerc. Sport, 66, 292-297

10. Biernat E. (2011), Aktywność fizyczna mieszkańców Warszawy. Na przykładzie wybranych grup zawodowych. Oficyna Wydawnicza. Szkoła Głowna Handlowa w Warszawie.

11. Blair S.N., Kohl H.W., Girdon N.F., Paffenbarger R.S., Jr (1992), How much physical activity is good for health? Annual Rev. Pub. Hlth. 13, 99-126

12. Booth M.L.,(2000), Assessment of Physical Activity: An International Perspective. Res. Quart. Exerc. Sport 71, 114-120

13. Borowiak E., Kostka T. (2003), Aktywność ruchowa starszych mieszkańców Łodzi. Medycyna Sportowa, nr 4. s. $139-146$

14. Bouchard C., Blair S.N., Haskell W.L. (ed.) (2007), Physical Activity and Health, Human Kinetics, Champaign

15. Bouchard C., Depres J.P. (1995), Physical activity and health. Atherosclerotic, metabolic and hypertensive diseases. Res. Quart. Exerc. Sport 66, 268-275

16. Bujanowska-Fedak M.M., Kumięga P., Sapilak B.J. (2013). Assessment of functional capacity of elderly persons in family practice based on selected scale tests. Family Medicine and Primary Care Review. Vol. 15, Iss 2, 76-79

17. Burns N., Paterson K., Watson N. (2009), An inclusive outdors? Disabled people's experiences of countryside bisure serrices. Source: Leisure Studies Vol. 28. Iss. 4. Pages: 403-17. DOI: 10.1080/02614360903071704. Published

18. Chale - Rush A., Guralnik I.M., Walkup M.P., Miller M.E., et.al (2010), Relationship between physical functioning and physical activity in the lifestyle interventions and independence for elders pilot. Journal of the American Seriatrices Scocjety. Vol. 58, Iss. 10, 1918-1924

19. Church T., Maeshall S.A., Zhang Q et. al. (2013), Physical activity increases gains in and prevents loss of physical function: Results from the lifestyle interventions and independence for elders pilot study. Journals of Gerontology - Series A Biological Sciences and Medical Sciences. Vol. 66, Iss. 4, 426-432.

20. Craig C.L., Marschall A.L., Sjöström M., Bauman A.E., Booth M.L., Ainsworth B.E., Pratt M., Elund U., Yngve A., Sallis J.F., Oja P. (2003), International Physical Activity Questionaire:12-Country Reliability and Validity. Med. Sci. Sport Exerc. 35, 1381-1395.

21. Drobnik J., Malcewicz M., Józefowski P., Kurpas D., Susło R., Steciwko A. (2010), Effects of physical definity in early adulthood on formation of positive old age - pilot survey. Family Medicine and Primary Care Review. Vol. 12, Iss. 3, 643-647.

22. Drygas W., Kwasniewska M., Szcześniewska D., Kozakiewicz K., Głusek J., Wiercińska E., Wykrzykowski B., Kurjata P. (2005), Ocena poziomu aktywności fizycznej dorosłej populacji Polski. Wyniki programu WOBASZ. Kardiologia Polska, 63:6 (supl.4) s. 1-5.

23. Drygas W., Skiba A., Bielecki W., Puska P. (2001), Ocena aktywności fizycznej mieszkańców sześciu krajów europejskich. Medicina Sportiva 5, Supl. 2, 119-128

24. Freeman I., Selmi N.(2010), French versus Canadian Tourism: Response to the Disabled. Journal of Travel Research. Vol.: 49, Iss. 4, Pages 471-85, DOI: 10. 1177/0047287509349268. Published: NOV

25. Gabryelewicz T., Mandecka M. (2013), Effects of physical activity on cognitive functions in older adults and the course of alzheimer's disease. Aktualności Neurologiczne, Vol. 13, Iss. 1, 56-61

26. Gray J.A., Zimmerman IL., Rimmer IH.(2012), Built environments for walkability, bikeability, and recreation: disability and universal design relevant? Disabil Health J; Apr.; 5(2): 87-101 
27. Ip E.H., Church T., Marshall S.A., Zhang Q, et.al (2013), Physical activity increases gains in and prevents loss of physical function: Results from the lifestyle interventions and independence for elders pilot study. Sciences and medical Sciences. Vol. 66, Iss. 4, 426-432

28. Kerr IL., Dattilo I., O'Sullivan D.(2012), Use of recreation activities as positive coping with chronić stress and mental health outcomes associated with unemployment of people with disabilities. Work:43(3): 279-92.

29. Knapik A., Rottermund J., Myśliwiec A., Plinta R., Gruca M. (2011), Aktywność fizyczna a samoocena zdrowia osób w starszym wieku. Przegląd Medyczny Uniwersytetu Rzeszowskiego i Narodowego Instytutu Leków w Warszawie, Nr.2, 195-204.

30. Knapik A., Saulicz E., Plinta R., Kuszewski M. (2011), Aktywność fizyczna a zdrowie kobiet w starszym wieku. Journal of Orthopaedic Trauma Surgery and Related Research.. Iss. 26, 27-33.

31. Kubińska Z., Bergier B., Bergier J. (2011), Uczestnictwo w turystyce i rekreacji ruchowej osób niepełnosprawnych zamieszkałych w miastach i wsiach województwa lubelskiego. Medycyna Ogólna i Nauki o Zdrowiu, Tom 17, Nr. 4, S. 189-193

32. Kubińska Z., Bergier B., Bergier J. (2013), Usage of leisure time by disabled males and females from the Lublin Region. Annals of Agricultural and Environmental Medicine. 2013, Vol. 20, No 2, s. 341-345.

33. Kübler M., Wójcik - Grzyb A. (2010), Motywy i korzyści podejmowania aktywności fizycznej w ocenie kobiet w średnim i starszym wieku. Medycyna Sportowa, t. 26, nr 5 s. 253-259

34. Lee I.M. (1995), Exercise and physical health. Cancer and immune function. Res. Quart. Exerc. Sport 66, 286281

35. Nowak M.(2009), Wpływ aktywności fizycznej na prawidłowq masę ciała kobiet po 60 roku życia. Aktywność ruchowa kobiet. Formy, uwarunkowania, korzyści i zagrożenia. AWF Warszawa

36. Osiński W. (2002), Aktywność fizyczna podejmowana przez osoby w podeszłym wieku. W: Antropomotoryka red. E. Mleczko. AWF Kraków.

37. Osiński W. (2013), Gerokinezjologia. Nauka i praktyka aktywności fizycznej w wieku starszym. Wydawnictwo Lekarskie. PZWL

38. Pańczyk W. (2010), Aktywność fizyczna mieszkańców południowo-wschodnich regionów Polski u progu XXI wieku. W: Społeczno-edukacyjne oblicza współczesnego sportu i olimpizmu. Aktywność fizyczna dzieci, młodzieży i dorosłych na przełomie XX i XXI wieku. red. J. Nowocień, J. Chełmecki. AWF Warszawa. Polska Akademia Olimpijska. Fundacja „Centrum Edukacji Olimpijskiej”. Warszawa

39. Patel K.V., Coppin A.K., Manini T.M., Lauretani F., et.al (2006), Midlife Physical Activity and Mobility in Older Age. The InChianti Study. American Journal of Preventive Medicine. Vol. 31, Iss. 3, 217-224.

40. Piątkowska M. (2010), Uczestnictwo Polaków w aktywności fizycznej w porównaniu do innych krajów Unii Europejskiej. W: Współczesne metody badań aktywności, sprawności i wydolności fizycznej człowieka. red. K. Buśko, J. Charzewska, K. Kaczanowski. AWF Warszawa

41. Romanowicz W., Bergier J., Tomczyszyn D. (2013), Age as a Differential Factor of the Activity of Disabled People in the Rural Areas of the Lubelskie Voivodship. Barometr Regionalny, T. 11, nr 1, s. 71-79

42. Rowiński R., Dąbrowski A. (2011), Wpływ regularnej aktywności ruchowej na sprawność fizycznq i jakość życia seniora. Turystyka i Rekreacja, nr 7, s. 109-114

43. Sirkka A., Merilampi S., Koivisto A., Leinonen M., Leino M. (2012), User experience of mobile controlled games for activation, rehabilitation and recreation of elderly physically impaired. Stud Health Technol Inform; 177; $289-95$

44. Tomczyszyn D., Bergier J.,Szczygielska E., Matusiak P. (2012), Aktywność zawodowa osób z niepełnosprawnościq w opiniach osób niepełnosprawnych pochodzq̨cych z terenów wiejskich województwa lubelskiego i pracodawców : prezentacja wyników badań. W: Aktywność zawodowa osób z niepełnosprawnością. Wydawnictwo PSW im. Papieża Jana Pawła II w Białej Podlaskiej, s. 11-51

45. Uczestnictwo Polaków w sporcie i rekreacji ruchowej. GUS, Warszawa 2009

46. Uczestnictwo Polaków w sporcie i rekreacji ruchowej (w okresie 1.X 1998- 30.IX.1999r.)

47. Vuori I. (1995), Exercise and physical health. Musculoskeletal health and functional capabilities. Res. Quart. Exerc. Sport 66, 276-285

48. Zatoński W.W. i wsp. (2011), Wyrównywanie różnic w zdrowiu między krajami Unii Europejskiej. Centrum Onkologii- Instytut Marii Skłodowskiej-Curie. Warszawa

49. Ż̇ikowski J., Dąbrowski D., Kuźmicki M. (2012), Determinanty aktywności zawodowej osób niepełnosprawnych zamieszkałych na obszarach wiejskich. Raport z badań. Państwowa Szkoła Wyższa w Białej Podlaskiej

Submitted: 26.05 .2014

Accepted: 16.06 .2014 